\title{
Research Article: Effect of sowing dates on white rust caused by Albugo candida in mustard
}

\author{
SUNITA J. MAGAR, SEETA S. SALUNKE AND A. P. SURYAWANSHI
}

Article Chronicle: Received :

17.07.2017;

Accepted :

01.08 .2017

KEY WoRds:

Brassica juncea, White rust, Albugo candida, Sowing dates, Incidence, Severity, Seed yield
SUMMARY : Mustard (Brassica juncea) is one of the major Rabi oilseed crops containing 30 to 48 per cent oil in India, being next in importance to groundnut, both in area and production, containing 30 to 48 per cent oil. White rust incited by Albugo candida (Pers. Ex. Lev.) Kuntz is an economically important and widely distributed disease of mustard and other cruciferous crops grown worldwide causing yield losses to the tune of 17 to $34 \%$. Therefore, present field study was carried out by sowing mustard cv. PUSA BOLD at five different dates, replicated four times in RBD, during Rabi, 2014-15. The results indicated that, the crop on $1^{\text {st }}$ Oct. $\left(\mathrm{D}_{1}\right)$ exhibited minimum disease incidence $(15.84 \%)$ and severity $(12.75 \%)$ while, maximum disease incidence (34.10\% and $28.24 \%)$ and severity (17.59\% and $14.59 \%)$ were recorded in the crop sown late on $15^{\text {th }}$ Nov. $\left(\mathrm{D}_{4}\right)$ and $1^{\text {st }}$ Nov. $\left(\mathrm{D}_{3}\right)$, respectively. Staghead incidence was maximum in $1^{\text {st }}$ Oct. sown crop $\left(\mathrm{D}_{1}\right)(6.70 \%)$ with severity $(14.62 \%)$; whereas, incidence was minimum in $1^{\text {st }}$ Nov. sowing $\left(\mathrm{D}_{3}\right)(7.08 \%)$ with severity $(18.95 \%)$. Also, seed yield was high in the early sown crop i.e. $1^{\text {st }}$ Oct. sowing $\left(\mathrm{D}_{1}\right)(6.11 \mathrm{q} / \mathrm{ha})$, compared to other dates of sowing. It indicated that, early sowing recorded less disease incidence and severity and maximum seed yield.

How to cite this article : Magar, Sunita J., Salunke, Seeta S. and Suryawanshi, A. P. (2017). Effect of sowing dates on white rust caused by Albugo candida in mustard. Agric. Update, 12(TECHSEAR-6) : 1509-1513; DOI: 10.15740/HAS/AU/12.TECHSEAR(6)2017/1509-1513.
Author for correspondence :

\section{SUNITA J. MAGAR}

Department of Plant Pathology, College of Agriculture (V.N.M.K.V.), LATUR (M.S.) INDIA

Email: sunitamagar7@ rediffmail.com

See end of the article for authors' affiliations 